\title{
PENGARUH LATIHAN CIRCUIT WEIGHT TRAINING TERHADAP KEKUATAN DAN DAYA TAHAN OTOT
}

\section{Oleh: Ahmad Nasrulloh \\ Dosen Jurusan Pendidikan Kesehatan dan Rekreasi FIK UNY}

\section{Abstrak}

Penelitian ini bertujuan untuk mengetahui seberapa besar pengaruh latihan circuit weight training terhadap kekuatan dan daya tahan otot.

Penelitian ini menggunakan metode eksperimen dengan desain the one group pretest-posttest design. Populasi penelitian adalah mahasiswa IKORA angkatan 2009. Sampel dalam penelitian ini melibatkan seluruh mahasiswa prodi IKORA FIK UNY angkatan 2009 yang mengambil matakuliah konsentrasi Latihan Beban. Instrumen yang digunakan adalah menggunakan alat ukur berupa leg \& back dynamometer untuk mengukur kekuatan otot tungkai, hand grip dynamometer untuk mengukur kekuatan otot tangan (menggenggam), dan pull and push dynamometer untuk mengukur kekuatan otot tangan (menarik dan mendorong). Sedangkan untuk mengetahui daya tahan otot dengan melakukan tes push up, sit up dan pull up. Teknik analisis data menggunakan uji t untuk mengetahui perbedaan variabel antara pretest dan posttest pada kelompok eksperimen.

Hasil analisis penelitian menunjukkan bahwa $\{\mathrm{t} \mid \mathrm{t}<-2,160$ atau $\mathrm{t}>2,160\}$ dengan taraf signifikansi $\mathrm{p}=0,000<0,05$. Jadi dapat dibuktikan hipotesis penelitian secara signifikan yaitu: (1) Latihan circuit weight training memberikan pengaruh yang signifikan terhadap peningkatan kekuatan otot tungkai dengan hasil $t$ test $\{\mathrm{t}=-4,561$ atau 4,561\}, (2) Latihan circuit weight training tidak dapat memberikan pengaruh yang signifikan terhadap peningkatan kekukatan otot tangan (menggenggam) dengan hasil $t$ test adalah $\{\mathrm{t}=-1,539$ atau 1,539\}, (3) Latihan circuit weight training memberikan pengaruh yang signifikan terhadap peningkatan kekuatan otot tangan (menarik) dengan hasil $t$ test $\{\mathrm{t}=-4,040$ atau 4,040\}, (4) Latihan circuit weight training memberikan pengaruh yang signifikan terhadap peningkatan kekuatan otot tangan (mendorong) dengan $t$ test $\{\mathrm{t}=-3,998$ atau 3,998\}, (5) Latihan circuit weight training memberikan pengaruh yang signifikan terhadap peningkatan daya tahan otot tubuh bagian atas dengan hasil $t$ test $\{\mathrm{t}=-4,575$ atau 4,575\}, (6) Latihan circuit weight training memberikan pengaruh yang signifikan terhadap peningkatan daya tahan otot perut $t$ test $\{\mathrm{t}=-7,590$ atau 7,590\}, dan (7) Latihan circuit weight training memberikan pengaruh yang signifikan terhadap peningkatan daya tahan otot lengan dan bahu $t$ test $\{\mathrm{t}=-3,782$ atau 3,782$\}$.

Kata kunci: circuit weight training, kekuatan otot, daya tahan otot

Program Studi Ilmu Keolahragaan (Prodi IKORA) merupakan salah satu prodi yang ada di Fakultas Ilmu Keolahragaan Universitas Negeri Yogyakarta. Prodi ini diharapkan mampu mencetak lulusan yang memiliki kompetensi dalam bidang kebugaran jasmani, terapi dan 


\section{MEDIKORA Vol. VIII, No 2 April 2012}

rehabilisati, manajemen olahraga, dan adaptif. Dalam upaya menciptakan lulusan yang berkompeten diperlukan sarana dan prasarana yang memadahi. Adapaun sarana penunjang dalam kegiatan belajar mengajar bagi mahasiswa prodi IKORA yaitu antara lain: laboratorium kebugaran jasmani (fitnes centre), klinik terapi, laboratorium anatomi dan fisiologi, histologi, manajemen kolam renang, GOR, wisma olahraga, lapangan tenis, stadion atletik, lapangan basket, hall bulutangkis, hall senam, sport smart dan lain-lain.

Tenaga ahli dan konsentrasi keilmuan yang spesifik juga menjadi bagian yang tidak bisa ditinggalkan dalam upaya peningkatan kualitas lulusan prodi IKORA. Hal ini didukung oleh beberapa tenaga pengajar yang sudah lulus S-2 dengan kualifikasi basic keilmuan yang dapat dipertanggungjawabkan linieritasnya. Sedangkan konsentrasi keilmuan yang harus dimiliki oleh para mahasiswa IKORA adalah tentang Ilmu Kebugaran Jasmani, Ilmu Terapi dan Rehabilitasi, Ilmu Manajemen Olahraga dan Ilmu Adaptif.

Salah satu konsentrasi keilmuan yang diminati oleh sebagian mahasiswa prodi IKORA adalah tentang kebugaran jasmani. Kebugaran jasmani adalah kemampuan tubuh seseorang untuk melakukan tugas dan pekerjaan sehari-hari tanpa menimbulkan kelelahan yang berarti, sehingga tubuh masih memiliki simpanan tenaga untuk mengatasi beban kerja tambahan (Iskandar dkk., 1999: 4). Fokus konsentrasi ilmu tentang kebugaran jasmani yang harus dikuasai oleh mahasiswa adalah tentang teori dan metode latihan beban yang baik dan benar untuk dapat meningkatkan kebugaran jasmani. Jadi mahasiswa IKORA yang mengambil mata kuliah latihan beban harus mampu melakukan latihan-latihan sesuai dengan system latihan yang ada.

Sistem latihan dalam melakukan latihan beban (weight training) mempunyai berbagai program latihan. Adapun bentuk latihan yang dapat digunakan yaitu menggunakan set block system, compuond set sytem dan circuit weight training system. Beberapa sistem latihan mempunyai spesifikasi yang berbeda-beda. Pada dasarnya circuit weight training system adalah memadukan latihan beban dengan prinsip latihan sirkuit, pada awalnya latihan ini dirancang untuk meningkatkan daya tahan dan kekuatan otot sambil melatih sistem aerobik, selanjutnya berkembang untuk memperbaiki komposisi tubuh. Latihan beban ini terdiri atas beberapa macam latihan beban yang disusun menjadi beberapa station atau pos, dengan pembebanan ringan ulangan banyak, dilakukan beberapa seri atau sirkuit, di antara pos diberikan istirahat pendek atau tanpa istirahat, sedangkan di antara sirkuit diberikan istirahat yang lebih lama (Djoko, 2009: 67).

Mahasiswa harus mampu melakukan latihan beban sesuai dengan prinsip-prinsip serta takaran latihan. Apabila latihan beban dilakukan sesuai dengan prinsip dan takaran latihan 


\section{MEDIKORA Vol. VIII, No 2 April 2012}

diharapkan dapat memberikan hasil yang maksimal, sehingga tujuan dari program dapat tercapai. Di samping itu, juga akan memperoleh manfaat dari latihan beban seperti memiliki daya tahan paru jantung, tubuh yang ideal, kekuatan otot, daya tahan otot, dan fleksibititas sendi. Sehingga dapat dikatakan bahwa dengan latihan beban secara terukur, teratur, dan terprogram sesuai dengan dosis latihan dapat digunakan untuk meningkatkan komponen kebugaran jasmani yang berhubungan dengan kesehatan.

\section{KAJIAN TEORI}

\section{Pengertian Weight Training}

Salah satu sarana yang digunakan untuk latihan olahraga dapat dilakukan dengan menggunakan latihan beban (weight training). Menurut Suharjana (2007: 87) latihan beban (weight training) adalah latihan yang dilakukan secara sistematis dengan menggunakan beban sebagai alat untuk menambah kekuatan fungsi otot guna memperbaiki kondisi fisik atlet, mencegah terjadinya cedera atau untuk tujuan kesehatan. Latihan beban dapat dilakukan dengan menggunakan beban dari berat badan sendiri (beban dalam) atau menggunakan beban luar yaitu beban bebas (free weight) seperti dumbell, barbell, atau mesin beban (gym machine). Bentuk latihan yang menggunakan beban dalam yang paling banyak digunakan seperti chin-up, push-up, sit-up, ataupun back-up, sedangkan menggunakan beban luar sangatlah banyak dan bervariasi sesuai dengan tujuan latihan serta perkenaan ototnya.

Menurut Sadoso Sumosardjuno (1992: 39) latihan beban adalah suatu cara pemeliharaan kondisi badan dengan jalan gerakan yang berulang-ulang, misalnya mengerutkan bisep, mengangkat bahu dengan beban yang submaksimal, dan lain-lain. Sedangkan menurut Djoko (2009: 65) latihan beban (weight training) disebut juga resistance training adalah salah satu jenis latihan olahraga yang menggunakan beban sebagai sarana untuk memberikan rangsang gerak pada tubuh. Pada mulanya latihan beban dikembangkan untuk melatih otot terutama untuk meningatkan kekuatan dan daya tahan serta hipertrofi otot. Dalam perkembanganya weight training dapat dirancang untuk meningkatkan daya tahan paru jantung dan memperbaiki komposisi tubuh.

Beban yang dipergunakan dapat berupa bobot badan sendiri, dambel, barbel ataupun mesin beban (gym machine). Cara penggunaan peralatan latihan beban terdiri atas dua macam yaitu dengan mesin (gym) dan beban bebas (free weight). Masing-masing jenis peralatan beban itu memiliki kelebihan dan kekurangannya. Adapun menurut Djoko (2004: 39) kelebihan dan kekurangan pada masing-masing peralatan beban adalah sebagai berikut:

Tabel 1. Kelebihan dan Kekurangan Peralatan Beban (Djoko, 2004: 39) 


\begin{tabular}{|l|l|}
\hline \multicolumn{1}{|c|}{ Gym Machine } & \multicolumn{1}{c|}{ Free Weight } \\
\hline Kelebihan: & Kelebihan: \\
1. Aman. & 1. Gerakan leluasa. \\
2. Hemat waktu latihan. & 2. Variasi latihan banyak. \\
3. Praktis. & 3. Melatih otot secara lengkap. \\
4. Dapat digunakan siapa saja. & 4. Penambahan beban teliti. \\
5. Bisa berlatih sendiri. & 5. Beban maksimal tak terbatas. \\
\hline Kekurangan: & Kekurangan: \\
1. Gerakannya terbatas. & 1. Kurang aman. \\
2. Hanya melatih otot utama. & 2. Digunakan bagi orang yang \\
3. Penambahan beban kurang & sudah berpengalaman. \\
teliti. & 3. Waktu berlatih relatif lama. \\
4. Beban maksimal terbatas. & 4. Perlu spotter (pendamping- \\
& \multicolumn{2}{|c|}{ lain). } \\
\hline
\end{tabular}

\section{Circuit Weight Training}

Latihan beban dapat dilakukan dengan beberapa sistem atau metode yang berbedabeda. Salah satunya dengan latihan sirkuit atau lebih dikenal dengan circuit weight training. Latihan ini pada dasarnya adalah memadukan prinsip latihan beban dengan prinsip latihan sirkuit atau kontinyu, pada awalnya latihan ini dirancang untuk meningkatkan daya tahan dan kekuatan otot sambil melatih sistem aerobik, selanjutnya berkembang untuk memperbaiki komposisi tubuh. circuit weight training terdiri atas beberapa macam latihan beban yang disusun menjadi beberapa station atau pos, dengan pembebanan ringan ulangan banyak, dilakukan beberapa seri atau sirkuit, di antara pos diberikan istirahat pendek atau tanpa istirahat, sedangkan di antara sirkuit diberikan istirahat yang lebih lama.

Menurut Corbin and Lindsey yang dikutip oleh Djoko (2009: 69) karakter circuit weight training antara lain: terdiri atas beberapa jenis latihan, seri, istirahat antar latihan sedikit, repetisi banyak, beban ringan, mengangkat beban berulang-ulang, latihan dimulai dari otot kecil ke otot besar, dilakukan bergantian antara anggota gerak atas dan bawah. Secara umum takaran latihan ini yaitu:

Tabel 2. Komponen dan Takaran Latihan (Djoko, 2009: 69).

\begin{tabular}{|c|c|}
\hline Komponen & Takaran \\
\hline Beban (intensitas) & $40 \%-80 \%$ Kemampuan maksimal \\
\hline Jumlah Latihan atau Pos & $6-12$ \\
\hline Repetisi per Set & $10-25$ \\
\hline Sirkuit & $2-5$ \\
\hline Istirahat Antar pos & Tanpa istirahat-30 dt \\
\hline Istirahat Antar Sirkuit & $<1 \mathrm{mnt}$ \\
\hline Lama Latihan & $8-16 \mathrm{Mg}$ \\
\hline
\end{tabular}




\section{MEDIKORA Vol. VIII, No 2 April 2012}

Program ini dapat berjalan optimal dengan hasil yang memuaskan apabila dilakukan sesuai dengan takaran latihan yang ada. Program ini juga dapat diikuti dengan pengaturan pola makan yang baik serta istirahat yang sesuai. Dalam penelitian ini peneliti menggunakan 12 pos yaitu: chest press, leg press, vertical straction, buterfly, lower back, arm curl, leg extebtion, sit up, triceps extention, rowing, abdominal machine dan leg curl.

\section{Komponen Kebugaran Jasmani yang Berhubungan dengan Kesehatan}

Menurut Iskandar dkk. (1999: 5), kebugaran jasmani terdiri atas dua komponen dasar yang saling berkaitan, yaitu kebugaran statis (static fitness) dan kebugaran dinamis (dynamic fitness). Kebugaran statis berhubungan dengan sistem otot, tulang, komposisi tubuh (postur tubuh) dan kondisi kesehatan. Kebugaran dinamis terbagi menjadi dua kategori yaitu kebugaran jasmani yang berhubungan dengan kesehatan (health related fitness) dan kebugaran jasmani yang berhubungan dengan keterampilan (skill related fitness).

Menurut Sadoso Sumosardjuno (1992: 19) kebugaran jasmani yang berhubungan dengan kesehatan mempunyai empat komponen yaitu (1) ketahanan jantung dan peredaran darah (cardiovascular endurance), (2) kekuatan otot (strength), (3) ketahanan otot (muscular endurance), dan (4) kelentukan (fleksibility). Tidak jauh berbeda dengan pendapat Djoko (2004: 4), kebugaran yang berhubungan dengan kesehatan memiliki empat komponen dasar, yaitu: (1) daya tahan paru-jantung, (2) kekuatan dan daya tahan otot, (3) kelentukan, dan (4) komposisi tubuh.

Komponen kebugaran jasmani yang berhubungan dengan kesehatan ini sangat diperlukan oleh setiap orang untuk melakukan aktivitas atau pekerjaan dalam kehidupan sehari-hari dan menjaga kesehatan. Apabila seseorang memiliki kebugaran jasmani yang baik, akan dapat melakukan aktivitas atau pekerjaan secara efektif dengan rasa senang dan penuh semangat tanpa merasakan kelelahan yang berarti. Adapun penjelasan dari lima komponen kebugaran jasmani yang berhubungan dengan kesehatan adalah sebagai berikut:

\section{Daya Tahan Paru-Jantung}

Daya tahan paru-jantung yakni kemampuan paru-jantung mensuplai oksigen untuk kerja otot dalam jangka waktu lama (Djoko Pekik Irianto, 2004: 4). Kebugaran parujantung dapat diartikan sebagai kemampuan jantung yang melibatkan paru-paru, pembuluh darah, dan kelompok otot besar dalam melakukan aktivitas kerja yang ringan sampai intensitas kerja yang berat dalam waktu yang relatif lama dengan tidak mengalami 


\section{MEDIKORA Vol. VIII, No 2 April 2012}

kelelahan yang berarti. Daya tahan paru-jantung sangat penting untuk menunjang kerja otot yaitu dengan cara mengambil oksigen dan menyalurkan ke dalam otot yang aktif. Hal ini juga dipengaruhi oleh kemampuan tubuh dalam melakukan aktivitas dalam kehidupan sehari-hari untuk menggunakan oksigen secara efisien, artinya makin besar aktivitas kerja yang dilakukan semakin banyak pula oksigen yang dipakai oleh tubuh. Begitu pula sebaliknya, jika aktivitas kerja yang dilakukan makin kecil, penggunaan oksigen oleh tubuh makin sedikit. Daya tahan paru-jantung bagi anak usia sekolah ditunjukkan untuk mempertahankan kemampuan dalam melaksanakan aktivitas sehari-hari seperti bermain dan belajar. Begitu pula bagi yang sudah siap untuk bekerja, daya tahan paru- jantung juga sangat dibutuhkan, karena daya tahan paru-jantung sangat mempengaruhi produktivitas kerja.

\section{Kekuatan Otot}

Menurut Sadoso Sumosardjuno (1997: 6) kekuatan otot adalah kemampuan otototot untuk menggunakan tenaga maksimal atau mendekati maksimal, untuk mengangkat beban. Secara mekanis kekuatan otot ini didefinisikan sebagai gaya (force) yang dapat dihasilkan oleh otot atau sekelompok otot dalam kontraksi maksimal. Pada mahasiswa, latihan untuk meningkatkan kekuatan otot harus bersifat menyeluruh dan melibatkan alat gerak pasif maupun aktif. Kekuatan otot ini merupakan komponen yang penting bagi seseorang, karena kekuatan otot merupakan daya dukung gerakan dalam melakukan aktivitas kerja, sehingga dimerlukan latihan kekuatan otot secara teratur.

\section{Daya Tahan Otot}

Daya tahan otot adalah kemampuan otot untuk melakukan kontraksi secara terusmenerus pada tingkat intensitas sub maksimal (Iskandar dkk., 1999: 4). Menurut Junusul Hairy (1989: 208) daya tahan otot adalah berhubungan dengan kemampuan sekelompok otot dalam mempertahankan suatu usaha dalam waktu yang lama tanpa mengalami unjuk kerja. Daya tahan otot diperlukan untuk mempertahankan kegiatan yang sifatnya didominasi oleh penggunaan otot atau kelompok otot. Seperti halnya komponen lain, daya tahan otot hanya diperlukan sebatas kebutuhan dalam melakukan aktivitas otot. Daya tahan otot akan berkurang secara bertahap seiring dengan bertambahnya umur, tetapi penurunan daya tahan otot tidak terjadi secepat menurunnya kekuatan otot. Untuk mahasiswa daya tahan otot sangat diperlukan untuk melaksanakan kegiatan-kegiatan di sekolah.

\section{Fleksibilitas (Kelentukan)}




\section{MEDIKORA Vol. VIII, No 2 April 2012}

Fleksibilitas adalah kemampuan sendi untuk melakukan gerakan sendi secara maksimal (Iskandar dkk., 1999: 4), dengan kata lain fleksibilitas merupakan kemampuan sendi untuk melakukan gerakan secara maksimal di dalam ruang gerak sendi. Fleksibilitas menunjukkan besarnya pergerakan sendi secara maksimal sesuai dengan kemungkinan gerakan (range of movement). Kemampuan yang cepat dan lincah untuk mengubah arah sangat memerlukan fleksibilitas tubuh. Pada umumnya anak memiliki tingkat fleksibilitas yang sangat baik. Oleh karena itu latihan fleksibilitas tidak boleh berlebihan karena dapat berpengaruh tidak baik dan dapat merusak sikap tubuh itu sendiri.

\section{Komposisi Tubuh}

Komposisi tubuh adalah susunan tubuh yang digambarkan sebagai dua komponen yaitu lemak tubuh dan masa tubuh tanpa lemak (Iskandar dkk., 1999: 5). Komposisi tubuh meliputi dua hal yaitu indeks masa tubuh dan presentase lemak tubuh. Komposisi tubuh juga didefinisikan sebagai perbandingan berat tubuh berupa lemak dengan berat tubuh tanpa lemak yang dinyatakan dalam persentase lemak tubuh.

Pada prinsipnya untuk dapat meningkatkan kekuatan dan daya tahan otot diperlikan sebuah latihan, karena dengan latihan otot akan dapat berkontraksi sehingga akan terjadi perubahan fungsi otot. Menurut Santosa (2007: 176) rangsang untuk meningkatkan kekuatan dan daya tahan statis otot adalah keadaan anaerobik dalam otot yang disebabkan oleh karena adanya kekurangan darah, sedangkan rangsang untuk bertambahnya daya tahan dinamis pada otot ialah keadaan aerobik dalam otot. Jadi dapat dikatakan bahwa latihan kontraksi otot yang tepat latihan yang mampu merangsang otot untuk bekerja secara anaerobik dan aerobik. Latihan ini bertujuan untuk meningkatkan kekuatan dan daya tahan otot. Salah satu bentuk latihan untuk dapat meningkatkan kekuatan dan daya tahan otot adalah latihan beban dengan circuit weight training system.

\section{METODE PENELITIAN}

Jenis penelitian yang digunakan dalam penelitian ini adalah eksperimen. Menurut Zainuddin (1988: 56) penelitian eksperimental pada dasarnya adalah ingin menguji hubungan antara suatu sebab (cause) dengan akibat (effect). Dikatakan bahwa penelitian ini merupakan penelitian eksperimen karena penelitian ini akan menguji hubungan sebab dan akibat tentang pengaruh latihan circuit weight training terhadap peningkatan kekuatan dan daya tahan otot.

Desain penelitian menggunakan the one-group pretest-posttest design. Menurut Leedy (1980: 169) the one-group pretest-posttest design is a type of experiment where a single group has (1) a pre-experimental evaluation, than (2) the influence of the variable, and, 


\section{MEDIKORA Vol. VIII, No 2 April 2012}

finally (3) a post-experimental evaluation. Dari pendapat tersebut di atas dapat dikatakan bahwa the one-group pretest-posttest design adalah sebuah bentuk penelitian eksperimen di mana satu kelompok tersebut menjadi sebuah evaluasi sebelum eksperimen, kemudian memberikan pengaruh pada variabel dan terakhir memberikan sebuah evaluasi sesudah eksperimen. Jadi dapat dikatakan bahwa hasil pretest merupakan kontrol dari penelitian ini. Desain penelitian ini dapat digambarkan sebagai berikut:

01

$\mathbf{P}$

$\mathbf{O 2}$

\section{Keterangan:}

O1 : Pre test (tes awal)

$\mathrm{P} \quad$ : Treatment (perlakuan)

O2 : Post test (tes akhir)

Sumber: Zaenuddin (1988: 71)

Latihan beban dalam penelitian ini dilakukan secara sirkuit yang terdiri atas beberapa macam latihan beban yang disusun menjadi 12 station atau pos, dengan pembebanan $50 \%$ beban maksimal, repetisi 15 kali pengulangan, dilakukan sebanyak 3 seri atau sirkuit, di antara pos diberikan istirahat 30 detik, sedangkan di antara sirkuit diberikan istirahat 1 menit. Adapun 12 pos yang dilakukan adalah: chest press, leg press, vertical straction, buterfly, lower back, arm curl, leg extention, sit up, triceps extention, rowing, abdominal machine dan leg curl. Instrumen untuk mengumpulkan data kekuatan otot dalam penelitian ini menggunakan alat ukur berupa leg \& back dynamometer, hand grip dynamometer, dan pull and push dynamometer. Sedangkan instrument untuk mengukur daya tahan otot adalah dengan push up, sit up dan pull up.

\section{HASIL PENELITIAN DAN PEMBAHASAN}

Dari data penelitian yang diperoleh akan dianalisis dengan sisten SPSS computer untuk mengetahui hasil uji t dari data variabel kekuatan otot meliputi kekuatan otot tungkai, kekuatan otot tangan (hand grip), kekuatan otot tangan (pull), dan kekuatan otot tangan (push). Selain itu juga untuk mengetahui kemampuan daya tahan otot yang meliputi daya tahan otot tubuh bagian atas, daya tahan otot perut dan daya tahan otot lengan dan bahu.

Uji t dilakukan untuk mengetahui apakah terdapat perbedaan kekuatan dan daya tahan otot antara pretest dan posttest pada kelompok eksperimen. Hasil analisis dinyatakan terdapat perbedaan jika nilai signifikansi kurang dari 0,05 $(p<0,05)$. variabel kekuatan otot meliputi kekuatan otot tungkai, kekuatan otot tangan (hand grip), kekuatan otot tangan (pull), dan 
kekuatan otot tangan (push). Selain itu juga untuk mengetahui kemampuan daya tahan otot yang meliputi daya tahan otot tubuh bagian atas, daya tahan otot perut dan daya tahan otot lengan dan bahu dapat dilihat pada Tabel 3 berikut ini.

Tabel 3. Hasil Uji t Variabel Kekuatan dan Daya Tahan Otot

\begin{tabular}{|c|c|c|c|c|}
\hline \multirow{2}{*}{$\begin{array}{l}\text { Komponen Kekuatan } \\
\text { dan Daya Tahan Otot }\end{array}$} & \multicolumn{2}{|c|}{ Hasil Analisis } & \multirow{2}{*}{ Keterangan } & \multirow{2}{*}{ Ket. Sig. } \\
\hline & $t$ & Sig. (p) & & \\
\hline Kekuatan Otot Tungkai & 4.561 & 0.000 & $\mathrm{p}<0.05$ & Signifikan \\
\hline $\begin{array}{l}\text { Kekuatan Otot Tangan } \\
\text { (Hand Grip/ } \\
\text { Menggenggam) }\end{array}$ & 1.539 & 0.145 & $\mathrm{p}>0.05$ & $\begin{array}{c}\text { Tidak } \\
\text { Signifikan }\end{array}$ \\
\hline $\begin{array}{l}\text { Kekuatan Otot Tangan } \\
\text { (Pull/ Menarik) }\end{array}$ & 4.040 & 0.001 & $\mathrm{p}<0.05$ & Signifikan \\
\hline $\begin{array}{l}\text { Kekuatan Otot Tangan } \\
\text { (Push/ Mendorong) }\end{array}$ & 3.998 & 0.001 & $\mathrm{p}<0.05$ & Signifikan \\
\hline $\begin{array}{l}\text { Daya Tahan Otot Tubuh } \\
\text { Bagian Atas }\end{array}$ & 4.575 & 0.000 & $\mathrm{p}<0.05$ & Signifikan \\
\hline Daya Tahan Otot Perut & 7.590 & 0.000 & $\mathrm{p}<0.05$ & Signifikan \\
\hline $\begin{array}{l}\text { Daya Tahan Otot Lengan } \\
\text { dan bahu }\end{array}$ & 3.782 & 0.002 & $\mathrm{p}<0.05$ & Signifikan \\
\hline
\end{tabular}

Hasil uji t kekuatan otot antara pretest dan posttest pada kelompok eksperimen dapat diketahui bahwa: (1) terdapat perbedaan antara pretest dan posttest kelompok eksperimen dengan nilai signifikansi pada kekuatan otot tungkai dengan nilai $\mathrm{p}=0,000$ dan $\mathrm{t}=4.161$, (2) tidak ada perbedaan antara pretest dan posttest kelompok eksperimen dengan nilai signifikansi pada kekuatan otot tangan (menggemnggam) dengan nilai $\mathrm{p}=0,145$ dan $\mathrm{t}=$ 1.539 , (3) terdapat perbedaan antara pretest dan posttest kelompok eksperimen dengan nilai signifikansi pada kekuatan otot tangan (pull) dengan nilai $\mathrm{p}=0,001$ dan $\mathrm{t}=4.040$, dan (4) terdapat perbedaan antara pretest dan posttest kelompok eksperimen dengan nilai signifikansi pada kekuatan otot tangan (push) dengan nilai $\mathrm{p}=0,001$ dan $\mathrm{t}=3.998$. 


\section{MEDIKORA Vol. VIII, No 2 April 2012}

Hasil uji $\mathrm{t}$ daya tahan otot antara pretest dan posttest pada kelompok eksperimen dapat diketahui bahwa: (1) terdapat perbedaan antara pretest dan posttest kelompok eksperimen dengan nilai signifikansi pada daya tahan otot tubuh bagian atas dengan nilai $\mathrm{p}=0,000$ dan $\mathrm{t}$ $=4.575$, (2) terdapat perbedaan antara pretest dan posttest kelompok eksperimen dengan nilai signifikansi pada daya tahan otot perut dengan nilai $p=0,000$ dan $t=7.590$, dan (3) terdapat perbedaan antara pretest dan posttest kelompok eksperimen dengan nilai signifikansi pada daya tahan otot lengan dan bahu dengan nilai $\mathrm{p}=0,002$ dan $\mathrm{t}=3.782$.

Hasil analisis penelitian menunjukkan bahwa $\{\mathrm{t} \mid \mathrm{t}<-2,160$ atau $\mathrm{t}>2,160\}$ dengan taraf signifikansi $\mathrm{p}=0,000<0,05$. Jadi dapat dibuktikan hipotesis penelitian secara signifikan yaitu: (1) Latihan circuit weight training memberikan pengaruh yang signifikan terhadap peningkatan kekuatan otot tungkai dengan hasil $t$ test $\{\mathrm{t}=-4,561$ atau 4,561\}, (2) Latihan circuit weight training tidak dapat memberikan pengaruh yang signifikan terhadap peningkatan kekukatan otot tangan (menggenggam) dengan hasil $t$ test adalah $\{\mathrm{t}=-1,539$ atau 1,539\}, (3) Latihan circuit weight training memberikan pengaruh yang signifikan terhadap peningkatan kekuatan otot tangan (menarik) dengan hasil $t$ test $\{\mathrm{t}=-4,040$ atau $4,040\}$, (4) Latihan circuit weight training memberikan pengaruh yang signifikan terhadap peningkatan kekuatan otot tangan (mendorong) dengan $t$ test $\{\mathrm{t}=-3,998$ atau 3,998\}, (5) Latihan circuit weight training memberikan pengaruh yang signifikan terhadap peningkatan daya tahan otot tubuh bagian atas dengan hasil $t$ test $\{t=-4,575$ atau 4,575$\}$, (6) Latihan circuit weight training memberikan pengaruh yang signifikan terhadap peningkatan daya tahan otot perut $t$ test $\{\mathrm{t}=-7,590$ atau 7,590\}, dan (7) Latihan circuit weight training memberikan pengaruh yang signifikan terhadap peningkatan daya tahan otot lengan dan bahu t test $\{\mathrm{t}=-3,782$ atau 3,782$\}$.

\section{PEMBAHASAN}

Latihan beban yang dilakukan dengan sistem circuit weight training ini akan dapat memberikan rangsangan terhadap otot. Rangsangan ini bertujuan untuk dapat meningkatkan kekuatan dan daya tahan otot. Beberapa kelompok otot yang diberikan rangsangan dalam penelitian ini agar terjadi peningkatan adalah kelompok otot-otot besar yang terdiri atas pectoralis, hamstring, quadriceps, lattisimis dorsi, low back, bisceps, trisceps, dan abdominal. Latihan ini dilakukan secara sirkuit yang terdiri atas beberapa macam latihan beban yang disusun menjadi 12 station atau pos, yaitu: chest press, leg press, vertical straction, buterfly, lower back, arm curl, leg extention, sit up, triceps extention, rowing, 


\section{MEDIKORA Vol. VIII, No 2 April 2012}

abdominal machine dan leg curl. Setelah dilakukan latihan tersebut diperoleh hasil sebagai beriku:

\section{Kekuatan Otot Tungkai}

Penelitian yang telah dilakukan ini menunjukkan bahwa kekuatan otot tungkai dari 16 mahasiswa yang mengambil konsentrasi kuliah latihan beban mengalami peningkatan yang signifikan. Hal ini dapat dilihat dari taraf signifikansi yang kurang dari 0,05 yaitu 0,000. Fakta empiris dari hasil penelitian menunjukkan rerata pada pretest kekuatan otot tungkai yaitu 20,544, sedangkan rerata posttest adalah 22,303.

Berdasarkan hasil penelitian yang telah dilakukan menunjukkan bahwa ada perbedaan antara rerata pretest dan posttest, sehingga dapat dikatakan bahwa kekuatan otot tungkai peserta tes mengalami peningkatan signifikan yang ditunjukkan dengan perbedaan rerata yaitu 20,544 menjadi 22,303. Peningkatan hasil pada penelitian ini dapat dilihat apabila dihitung selisih antara rerata pretest dan posttest yaitu 22,303-20,544= 1,759. Jadi dapat disimpulkan bahwa latihan circuit weight training dapat meningkatkan kekuatan otot tungkai sebesar 1,759.

\section{Kekuatan Otot Tangan (Hand Grip/Menggenggam)}

Penelitian yang telah dilakukan ini menunjukkan bahwa kekuatan otot tangan (menggenggam) dari 16 mahasiswa yang mengambil konsentrasi kuliah latihan beban tidak mengalami peningkatan yang signifikan. Hal ini dapat dilihat dari taraf signifikansi yang lebih dari 0,05 yaitu 0,145. Berdasarkan hasil penelitian yang telah dilakukan menunjukkan bahwa tidak ada perbedaan antara rerata pretest dan posttest, sehingga dapat dikatakan bahwa kekuatan otot tangan (menggemnggam) peserta tes tidak mengalami peningkatan signifikan. Jadi dapat disimpulkan bahwa latihan circuit weight training tidak dapat meningkatkan kekuatan menggenggam otot tangan.

\section{Kekuatan Otot Tangan (Pull/Menarik)}

Penelitian yang telah dilakukan ini menunjukkan bahwa kekuatan otot tangan (menarik) dari 16 mahasiswa yang mengambil konsentrasi kuliah latihan beban mengalami peningkatan yang signifikan. Hal ini dapat dilihat dari taraf signifikansi yang kurang dari 0,05 yaitu 0,001. Fakta empiris dari hasil penelitian menunjukkan rerata pada pretest kekuatan otot tangan (menarik) yaitu 27,5312, sedangkan rerata posttest adalah 30,8875 .

Berdasarkan hasil penelitian yang telah dilakukan menunjukkan bahwa ada perbedaan antara rerata pretest dan posttest, sehingga dapat dikatakan bahwa kekuatan otot tangan (menarik) peserta tes mengalami peningkatan signifikan yang ditunjukkan 


\section{MEDIKORA Vol. VIII, No 2 April 2012}

dengan perbedaan rerata yaitu 27,5312 menjadi 30,8875. Peningkatan hasil pada penelitian ini dapat dilihat apabila dihitung selisih antara rerata pretest dan posttest yaitu $30,8875-27,5312=3,3563$. Jadi dapat disimpulkan bahwa latihan circuit weight training dapat meningkatkan kekuatan otot tangan (menarik) sebesar 3,3563.

\section{Kekuatan Otot Tangan (Push/Mendorong)}

Penelitian yang telah dilakukan ini menunjukkan bahwa kekuatan otot tangan (mendorong) dari 16 mahasiswa yang mengambil konsentrasi kuliah latihan beban mengalami peningkatan yang signifikan. Hal ini dapat dilihat dari taraf signifikansi yang kurang dari 0,05 yaitu 0,001. Fakta empiris dari hasil penelitian menunjukkan rerata pada pretest kekuatan otot tangan (mendorong) yaitu 25,7188, sedangkan rerata posttest adalah 29,0875 .

Berdasarkan hasil penelitian yang telah dilakukan menunjukkan bahwa ada perbedaan antara rerata pretest dan posttest, sehingga dapat dikatakan bahwa kekuatan otot tangan (mendorong) peserta tes mengalami peningkatan signifikan yang ditunjukkan dengan perbedaan rerata yaitu 25,7188 menjadi 29,0875. Peningkatan hasil pada penelitian ini dapat dilihat apabila dihitung selisih antara rerata pretest dan posttest yaitu $29,0875-25,7188=3,3687$. Jadi dapat disimpulkan bahwa latihan circuit weight training dapat meningkatkan kekuatan otot tangan (mendorong) sebesar 3,3687.

\section{Daya Tahan Otot Tubuh Bagian Atas}

Penelitian yang telah dilakukan ini menunjukkan bahwa daya tahan otot tubuh bagian atas dari 16 mahasiswa yang mengambil konsentrasi kuliah latihan beban mengalami peningkatan yang signifikan. Hal ini dapat dilihat dari taraf signifikansi yang kurang dari 0,05 yaitu 0,000 . Fakta empiris dari hasil penelitian menunjukkan rerata pada pretest daya tahan otot tubuh bagian atas yaitu 28,31, sedangkan rerata posttest adalah 31,25 .

Berdasarkan hasil penelitian yang telah dilakukan menunjukkan bahwa ada perbedaan antara rerata pretest dan posttest, sehingga dapat dikatakan bahwa daya tahan otot tubuh bagian atas peserta tes mengalami peningkatan signifikan yang ditunjukkan dengan perbedaan rerata yaitu 28,31 menjadi 31,25. Peningkatan hasil pada penelitian ini dapat dilihat apabila dihitung selisih antara rerata pretest dan posttest yaitu 31,25-28,31 $=2,94$. Jadi dapat disimpulkan bahwa latihan circuit weight training dapat meningkatkan daya tahan otot tubuh bagian atas sebesar 2,94. 


\section{MEDIKORA Vol. VIII, No 2 April 2012}

\section{Daya Tahan Otot Perut}

Penelitian yang telah dilakukan ini menunjukkan bahwa daya tahan otot perut dari 16 mahasiswa yang mengambil konsentrasi kuliah latihan beban mengalami peningkatan yang signifikan. Hal ini dapat dilihat dari taraf signifikansi yang kurang dari 0,05 yaitu 0,000. Fakta empiris dari hasil penelitian menunjukkan rerata pada pretest daya tahan otot perut yaitu 26,19, sedangkan rerata posttest adalah 30,56.

Berdasarkan hasil penelitian yang telah dilakukan menunjukkan bahwa ada perbedaan antara rerata pretest dan posttest, sehingga dapat dikatakan bahwa daya tahan otot perut peserta tes mengalami peningkatan signifikan yang ditunjukkan dengan perbedaan rerata yaitu 26,19 menjadi 30,56. Peningkatan hasil pada penelitian ini dapat dilihat apabila dihitung selisih antara rerata pretest dan posttest yaitu 30,56-26,19= 4,37. Jadi dapat disimpulkan bahwa latihan circuit weight training dapat meningkatkan daya tahan otot perut sebesar 4,37.

\section{Daya Tahan Otot Lengan dan Bahu}

Penelitian yang telah dilakukan ini menunjukkan bahwa daya tahan otot lengan dan bahu dari 16 mahasiswa yang mengambil konsentrasi kuliah latihan beban mengalami peningkatan yang signifikan. Hal ini dapat dilihat dari taraf signifikansi yang kurang dari 0,05 yaitu 0,002 . Fakta empiris dari hasil penelitian menunjukkan rerata pada pretest daya tahan otot lengan dan bahu yaitu 14,00, sedangkan rerata posttest adalah 15,06.

Berdasarkan hasil penelitian yang telah dilakukan menunjukkan bahwa ada perbedaan antara rerata pretest dan posttest, sehingga dapat dikatakan bahwa daya tahan otot lengan dan bahu peserta tes mengalami peningkatan signifikan yang ditunjukkan dengan perbedaan rerata yaitu 14,00 menjadi 15,06 . Peningkatan hasil pada penelitian ini dapat dilihat apabila dihitung selisih antara rerata pretest dan posttest yaitu 15,06-14,00 $=1,06$. Jadi dapat disimpulkan bahwa latihan circuit weight training dapat meningkatkan daya tahan otot lengan dan bahu sebesar 1,06.

\section{KESIMPULAN}

Dari uraian pembahasan tersebut dapat disimpulkan bahwa latihan circuit weight training yang diberikan sesuai dosis dan takaran latihan dapat memberikan pengaruh yang signifikan terhadap kekuatan otot. Adapun kekuatan otot yang mengalami peningkatan signifikan adalah kekuatan otot tungkai, kekuatan otot tangan (menarik) dan kekuatan otot tangan (mendorong). Sedangkan kekuatan otot tangan menggenggam tidak mengalami peningkatan yang signifikan. Hal ini disebabkan latihan yang dilakukan tidak 


\section{MEDIKORA Vol. VIII, No 2 April 2012}

banyak menggunakan kekuatan menggenggam akan tetapi lebih banyak difokuskan pada latihan untuk melatih otot-otot besar.

Selain kekuatan otot, latihan circuit weight training ini juga dapat meningkatkan kemampuan daya tahan otot. Adapun peningkatan daya tahan otot yang signifikan setelah diberikan perlakuan berupa latihan circuit weight training ini yaitu terjadinya peningkatan daya tahan otot tubuh bagian atas, daya tahan otot perut dan daya tahan otot lengan dan bahu. Jadi dapat ditarik sebuah kesimpulan bahwa latihan circuit weight training dapat memberikan pengaruh yang signifikan terhadap kekuatan otot tungkai, kekuatan otot tangan (menarik), kekuatan otot tangan (mendorong), daya tahan otot tubuh bagian atas, daya tahan otot perut dan daya tahan otot lengan dan bahu

\section{DAFTAR PUSTAKA}

Djoko, Pekik Irianto. (2000). Panduan Latihan Kebugaran (yang Efektif dan Aman). Yogyakarta: Lukman Offset. . (2004). Pedoman Praktis Berolahraga. Yogyakarta: Andi Offset. . (2009). Peranan Jogging dan Circuit Weight Training pada Profil Lemak Tubuh dan Kebugaran Aerobik Penyandang Overweight. Makalah, tidak diterbitkan, Universitas Negeri Surabaya. Surabaya

H.Y.S Santosa Giriwijoyo, (2007). Ilmu Faal Olahraga. Bandung: UPI.

Iskandar Z. Adisapoetra, dkk. (1999). "Panduan Teknis Tes \& Latihan Kesegaran Jasmani." Seminar. Jakarta: Pusat Pengkajian dan Pengembangan IPTEK Olahraga Kantor Menpora.

Junusul Hairy. (1989). Fisiologi Olahraga. Jakarta: Departemen Pendidikan dan Kebudayaan.

Leedy, P. D. (1980). Practical Research. New York: Macmillan Publishing Co. Inc.

Sadoso Sumosardjuno. (1992). Pengetahuan Praktis Kesehatan dalam Olahraga. Jakarta: PT Gramedia Pustaka Utama.

Suharjana. (2007). Latihan Beban: Sebuah Metode Latihan Kekuatan. Jurnal Ilmiah Kesehatan Olahraga, MEDIKORA, Vol. III, No.1, 80-101.

Zaenudin, M. 1988. Metodologi Penelitian. Surabaya: Universitas Airlangga. 